\title{
Review \\ SNX-PXA-RGS-PXC Subfamily of SNXs in the Regulation of Receptor-Mediated Signaling and Membrane Trafficking
}

\author{
Bibhas Amatya ${ }^{1,+}$, Hewang Lee ${ }^{2,+}$, Laureano D. Asico ${ }^{2}(D)$ Prasad Konkalmatt ${ }^{2}$, Ines Armando ${ }^{2}$, Robin A. Felder ${ }^{3}$ \\ and Pedro A. Jose $2,3,4, *$
}

check for

updates

Citation: Amatya, B.; Lee, H.; Asico, L.D.; Konkalmatt, P.; Armando, I.; Felder, R.A.; Jose, P.A. SNX-PXA-RGS-PXC Subfamily of SNXs in the Regulation of Receptor-Mediated Signaling and Membrane Trafficking. Int. J. Mol. Sci. 2021, 22, 2319. https://doi.org/ $10.3390 /$ ijms22052319

Academic Editor: Martin Hohenegger

Received: 21 January 2021

Accepted: 22 February 2021

Published: 26 February 2021

Publisher's Note: MDPI stays neutral with regard to jurisdictional claims in published maps and institutional affiliations.

Copyright: (c) 2021 by the authors. Licensee MDPI, Basel, Switzerland. This article is an open access article distributed under the terms and conditions of the Creative Commons Attribution (CC BY) license (https:/ / creativecommons.org/licenses/by/ $4.0 /)$.
1 The George Washington University, Washington, DC 20052, USA; bibhasamatya78@gwmail.gwu.edu

2 Department of Medicine, The George Washington University School of Medicine \& Health Sciences, Washington, DC 20052, USA; lih@gwu.edu (H.L.); lasico@email.gwu.edu (L.D.A.); prk@email.gwu.edu (P.K.); iarmando@email.gwu.edu (I.A.)

3 Department of Pathology, University of Virginia Health Sciences Center, Charlottesville, VA 22908, USA; raf7k@virginia.edu

4 Department of Pharmacology/Physiology, The George Washington University School of Medicine \& Health Sciences, Washington, DC 20052, USA

* Correspondence: pjose@mfa.gwu.edu

+ These authors contributed equally to this work.

\begin{abstract}
The SNX-PXA-RGS-PXC subfamily of sorting nexins (SNXs) belongs to the superfamily of SNX proteins. SNXs are characterized by the presence of a common phox-homology (PX) domain, along with other functional domains that play versatile roles in cellular signaling and membrane trafficking. In addition to the PX domain, the SNX-PXA-RGS-PXC subfamily, except for SNX19, contains a unique RGS (regulators of G protein signaling) domain that serves as GTPase activating proteins (GAPs), which accelerates GTP hydrolysis on the G protein $\alpha$ subunit, resulting in termination of G protein-coupled receptor (GPCR) signaling. Moreover, the PX domain selectively interacts with phosphatidylinositol-3-phosphate and other phosphoinositides found in endosomal membranes, while also associating with various intracellular proteins. Although SNX19 lacks an RGS domain, all members of the SNX-PXA-RGS-PXC subfamily serve as dual regulators of receptor cargo signaling and endosomal trafficking. This review discusses the known and proposed functions of the SNXPXA-RGS-PXC subfamily and how it participates in receptor signaling (both GPCR and non-GPCR) and endosomal-based membrane trafficking. Furthermore, we discuss the difference of this subfamily of SNXs from other subfamilies, such as SNX-BAR nexins (Bin-Amphiphysin-Rvs) that are associated with retromer or other retrieval complexes for the regulation of receptor signaling and membrane trafficking. Emerging evidence has shown that the dysregulation and malfunction of this subfamily of sorting nexins lead to various pathophysiological processes and disorders, including hypertension.
\end{abstract}

Keywords: endosome; GPCR; receptor; RGS; signaling; SNX; trafficking

\section{Introduction}

Receptor-mediated signaling and membrane trafficking processes are intimately interconnected with the endosomes [1]. Internalized receptors, including G protein-coupled receptors (GPCRs) and non-GPCRs, are sorted at endosomes, from which receptors are either delivered to the lysosome for degradation, recycled back to the plasma membrane, or delivered to the trans-Golgi network (TGN) and other organelles by receptor-specific pathways [2,3]. Sorting nexins (SNXs) play critical roles in these processes [4].

The SNX family has a phox homology (PX) domain, capable of phosphoinositide binding, which enables SNX targeting to endosomal membranes by binding to phosphatidylinositols, most commonly phosphatidylinositol 3-phosphate (PI(3)P) $[5,6]$. SNXs are widely expressed from yeast to mammals, whose PX domain, first identified in two subunits of the NADPH oxidase, $\mathrm{p} 40^{\text {phox }}$ and $\mathrm{p} 47^{\text {phox }}$, actively engages in protein-lipid 
and protein-protein interactions [5,6]. To date, 10 yeast and 33 mammalian SNXs have been identified [5-8]. Based on their domain architectures, the mammalian SNXs are divided into five subfamilies: SNX-PXA-RGS-PXC, SNX-FERM (protein 4.1/ezrin/radixin/moesin), SNX-BAR (Bin/Amphiphysin/Rvs), SNX-PX, and the unclassified SNX subfamilies [7,8] (Table 1).

Table 1. Summary of mammalian sorting nexin (SNX) subfamilies [5-8].

\begin{tabular}{|c|c|c|c|}
\hline Subfamily * & Members & Major Domain Architecture ** & $\begin{array}{l}\text { Roles in Signaling, Trafficking, } \\
\text { and Degradation }\end{array}$ \\
\hline SNX-PXA-RGS-PXC (4) & $\begin{array}{l}\text { SNX13, SNX14, } \\
\text { SNX19, SNX25 }\end{array}$ & $P X A-R G S-P X-P X C-$ & $\begin{array}{l}\text { Plays important roles in receptor } \\
\text { signaling and membrane trafficking, } \\
\text { see text for details. }\end{array}$ \\
\hline SNX-FERM (3) & $\begin{array}{l}\text { SNX17, SNX27, } \\
\text { SNX31 }\end{array}$ & $P D Z-P X-$ FERM - & $\begin{array}{l}\text { Involved in cargo loading and } \\
\text { binding to membrane structures and } \\
\text { endosome to plasma membrane } \\
\text { trafficking or lysosomal degradation. }\end{array}$ \\
\hline SNX-BAR (12) & $\begin{array}{l}\text { SNX1, SNX2, SNX4, } \\
\text { SNX5, SNX6, SNX7, } \\
\text { SNX8, SNX9, SNX18, } \\
\text { SNX30, SNX32, } \\
\text { SNX33 }\end{array}$ & $P X-B A R$ & $\begin{array}{l}\text { Recognizes and targets to a wide } \\
\text { range of cargoes, in coordination with } \\
\text { retromers or other retrieval } \\
\text { machineries to regulate receptor } \\
\text { signaling and trafficking in } \\
\text { retromer-dependent and } \\
\text {-independent manners. }\end{array}$ \\
\hline SNX-PX (10) & $\begin{array}{l}\text { SNX3, SNX10, } \\
\text { SNX11, SNX12, } \\
\text { SNX16, SNX20, } \\
\text { SNX21, SNX22, } \\
\text { SNX24, SNX29 }\end{array}$ & $\underline{-}$ & $\begin{array}{l}\text { Forms endosome transport carriers in } \\
\text { retromer-dependent or -independent } \\
\text { manners on a diversity of cargo } \\
\text { sorting, retrograde protein trafficking, } \\
\text { and lysosomal degradation. }\end{array}$ \\
\hline Unclassified SNXs (4) & $\begin{array}{l}\text { SNX15, SNX23 } \\
\text { SNX26, SNX28 }\end{array}$ & PX & $\begin{array}{l}\text { Binds to endosomes in } \\
\mathrm{Ca}^{2+} \text {-dependent or -independent } \\
\text { manners; regulates cargoes, such as } \\
\text { amyloid- } \beta \text { precursor protein } \\
\text { recycling to cell surface and } \\
\text { processing for amyloid- } \beta \text { generation. }\end{array}$ \\
\hline
\end{tabular}

Note: * The classification is basically dependent on SNX proteins' domain architecture [6-8]. The number in the parenthesis indicates the number of the member proteins of the subfamilies. The unclassified SNX subfamily is comprised of unique SNX members that cannot be conveniently classified into the other four subfamilies. ${ }^{* *}$ For simplicity and clarity, the domain structure is not complete for all subfamily members. For example, the unclassified SNX subfamily has 4 members with structures in addition to PX domain. SNX15 contains a C-terminal MIT domain; SNX23 contains an N-terminal kinesin domain; and SNX26 has a C-terminal SH3 and RhoGAP domain. GAP, GTPase activating protein; MIT, microtubule interacting and trafficking; SH3, Src Homology 3.

\section{SNX-PXA-RGS-PXC Subfamily Domain Structure and Biochemical Properties}

The SNX-PXA-RGS-PXC subfamily is comprised of SNX13 (also known as RGS-PX1), SNX14, SNX19, and SNX25. This subfamily of SNXs contains two N-terminal helical transmembrane domains, followed by a PX-associated domain (PXA), a regulators of G protein signaling (RGS) domain, the PX domain, and a C-terminal PX-associated (PXC) domain $[6,8]$.

Integrated transmembrane domains (IMDs), which are two, close short hydrophobic sequences, are involved in membrane tethering [4,6]. RGS domain, a unique domain compared with other subfamily SNXs, is a conserved, approximately 130 amino acid residue-domain with a specific molecular configuration (Figure 1A). The PXA and PXC domains are largely uncharacterized. 
A

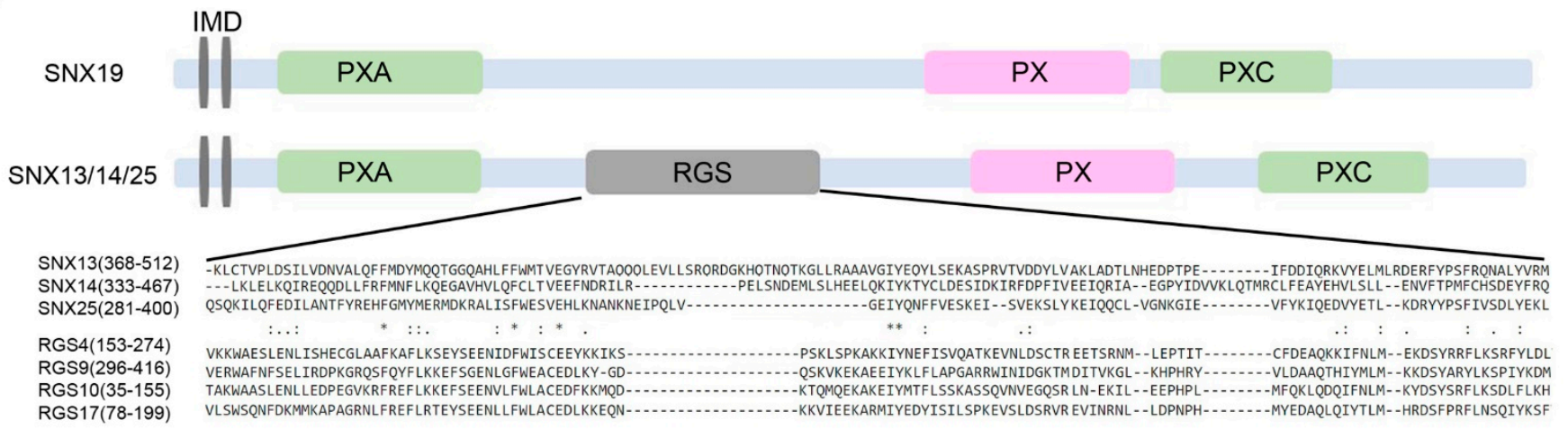

B

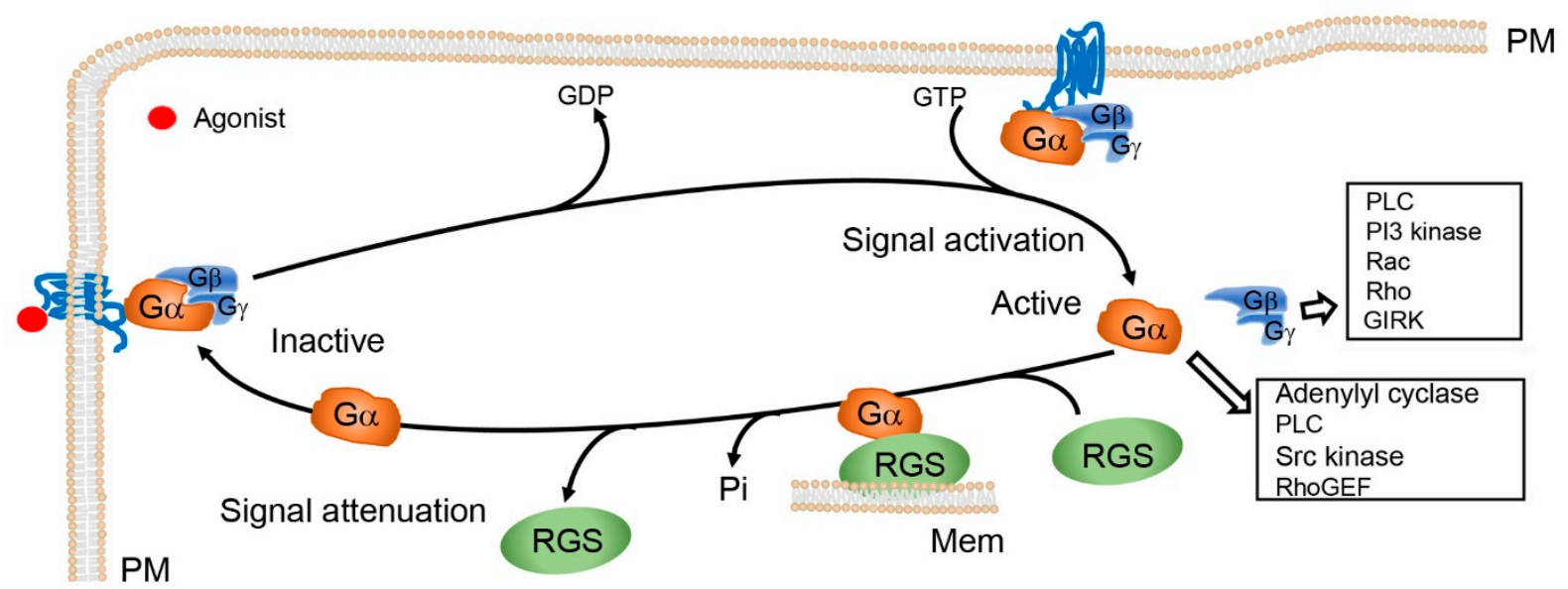

Figure 1. Unique RGS domain in the structure of SNX-PXA-RGS-PXC subfamily. (A) Domain organization of SNX-PXARGS-PXC subfamily. All members of this subfamily, except SNX19, have unique RGS domains, which are aligned with RGS proteins, as shown. Asterisk denotes identical amino acid residues among all of the seven peptides, one dot indicates the weakly conserved amino acid residues, and double dots indicate the well-conserved amino acid residues among all of the peptides. IMD, integrated transmembrane domain. (B) RGS proteins in the G protein nucleotide cycle. Upon agonist binding, receptors activate heterotrimeric G proteins, which induce the exchange of GDP for GTP and dissociation of $G \alpha$ from $G \beta \gamma$, attenuation of $G \alpha$ subunit's activation $\left(G \alpha_{s}\right)$ or inhibition $\left(G \alpha_{i}\right)$ of its downstream effectors. The effect is terminated by GTPase or the intrinsic GTPase activity of $G \alpha$, where RGS is separated from G $\alpha$ s. RGS proteins or SNX13 facilitates the hydrolysis of GTP by G $\alpha$ s, as a GTPase-activating protein. G $\alpha$, G alpha subunit; G $\beta$, G beta subunit; GDP, guanosine diphosphate; $\mathrm{G} \gamma, \mathrm{G}$ gamma subunit; GIRK, G protein-coupled inwardly rectifying potassium; GTP, guanosine triphosphate; Mem, intracellular membranes; PI3 kinase, phosphoinositide 3-kinase; PLC, phospholipase C; PM, plasma membrane; Rac, Rac G protein; RGS, regulators of G protein signaling; Rho, Rho G protein; RhoGEF, guanine nucleotide exchange factor for Rho; Scr kinase, Src family kinases.

The PX domain of the SNX-PXA-RGS-PXC subfamily is similar to the PX domains of all other SNX subfamilies, with around 100-130 residues, comprised of three $\beta$-strands and three $\alpha$-helices [8]. The conserved sequence $\Psi \operatorname{PxxPxK}$ ( $\Psi$ refers to any large aliphatic amino acid $\mathrm{V}, \mathrm{I}, \mathrm{L}$, or $\mathrm{M}$ ) forms a shallow, positively charged proline-rich loop that is considered to be the binding site of the negatively charged phosphate groups of phosphoinositides [4]. Phosphatidylinositol 3-phosphate (PI(3)P), primarily found in early endosome membranes, is a common target of SNXs [9]. This was confirmed from the analysis of the crystal structure of the SNX PX domains [4]. Although PI(3)P is the most common phosphoinositide bound to SNX, many other phosphoinositide interactions have also been demonstrated (Table 2) [5-27]. The PX domain acts not only as a lipid recognition module [7,11], but also plays a key role in protein-protein interactions, such as the interaction of SNX13 and 
SNX14 with Gas $[4,6]$ and SNX19 with IA2 [4,6] and $D_{1}$ R [20]. However, the molecular details of these interactions remain to be characterized further.

Table 2. Summary of the characteristics of SNX-PXA-RGS-PXC subfamily members.

\begin{tabular}{|c|c|c|c|c|c|}
\hline SNX & $\begin{array}{l}\text { Chromosomal } \\
\text { Locus }\end{array}$ & $\begin{array}{l}\text { Major Cellular } \\
\text { Distribution }\end{array}$ & $\begin{array}{l}\text { Major Tissue } \\
\text { Distribution }\end{array}$ & $\begin{array}{c}\text { Phosphoinositide } \\
\text { Binding } \\
\text { Preferences }\end{array}$ & References \\
\hline SNX13 & $\begin{array}{l}\text { 7p21(human) } \\
\text { 12(mouse) }\end{array}$ & $\begin{array}{l}\text { Endosome } \\
\text { ER }\end{array}$ & $\begin{array}{l}\text { Pancreas } \\
\text { Heart } \\
\text { CNS } \\
\text { Adipose } \\
\text { Spleen }\end{array}$ & $\begin{array}{c}\mathrm{PI}(3) \mathrm{P} \\
\mathrm{PI}(3,4) \mathrm{P}_{2} \\
\mathrm{PI}(3,5) \mathrm{P}_{2} \\
\mathrm{PI}(4,5) \mathrm{P}_{2} \\
\mathrm{PI}(3,4,5) \mathrm{P}_{3}\end{array}$ & {$[5-7,9-13]$} \\
\hline SNX14 & $\begin{array}{l}\text { 6q14(human) } \\
\text { 9(mouse) }\end{array}$ & $\begin{array}{c}\text { Lysosomes } \\
\text { ER } \\
\text { Lipid droplets }\end{array}$ & $\begin{array}{c}\text { CNS } \\
\text { Adipose } \\
\text { Lung } \\
\text { Heart } \\
\text { Testis }\end{array}$ & $\mathrm{PI}(3,5) \mathrm{P}_{2}$ & {$[5-7,9-11,13-17]$} \\
\hline SNX19 & $\begin{array}{c}\text { 11q24.3- } \\
\text { q25(human) } \\
9 \text { (mouse) }\end{array}$ & $\begin{array}{l}\text { Early endosomes } \\
\text { Plasma membrane } \\
\text { Mitochondria }\end{array}$ & $\begin{array}{c}\text { Kidney } \\
\text { CNS } \\
\text { Bone marrow } \\
\text { Heart } \\
\text { Pancreas }\end{array}$ & $\begin{array}{c}\mathrm{PI}(3) \mathrm{P} \\
\mathrm{PI}(4,5) \mathrm{P}_{2} \\
\mathrm{PI}(3,4,5) \mathrm{P}_{3}\end{array}$ & {$[5-7,9-11,18-23]$} \\
\hline SNX25 & $\begin{array}{l}\text { 4q35(human) } \\
8 \mathrm{~A} 4 \text { (mouse) }\end{array}$ & $\begin{array}{l}\text { Endosomes } \\
\text { Lysosomes } \\
\text { Nucleus }\end{array}$ & $\begin{array}{l}\text { Lung } \\
\text { Kidney } \\
\text { CNS }\end{array}$ & $\begin{array}{c}\mathrm{PI}(3,4) \mathrm{P}_{2} \\
\mathrm{PI}(3,5) \mathrm{P}_{2} \\
\mathrm{PI}(4,5) \mathrm{P}_{2} \\
\mathrm{PI}(3,4,5) \mathrm{P}_{3} \\
\mathrm{PI}(3) \mathrm{P}\end{array}$ & {$[5-7,9-11,23-27]$} \\
\hline
\end{tabular}

Abbreviations: CNS, central nervous system; ER, endoplasmic reticulum; PI, phosphoinositide; SNX, sorting nexin; TGN, transGolgi network.

The RGS domain is present in SNX13, SNX14, and SNX25, but not SNX19 [6] (Table 3). This domain is found in a number of molecules, including 20 canonical mammalian RGS proteins and an additional 19 proteins that mediate the interaction with GPCRs or G $\alpha$ subunits [28]. G proteins are activated by the binding of GTP to G $\alpha$ and separation from the $\mathrm{G} \beta \gamma$ dimer; the deactivation of $\mathrm{G}$ proteins occurs when GTP is hydrolyzed by the action of the GTPase-activating proteins (GAPs) (Figure 1B). RGS proteins bind to G $\alpha$ to facilitate the GTP hydrolysis, accelerating the termination of G protein signaling [29,30]. The SNX-PXARGS-PXC subfamily belongs to 19 noncanonical proteins that were previously considered nonfunctional [31]. Recent findings demonstrated that the RGS domain in SNX proteins, like canonical RGS proteins, is involved in the attenuation of GPCR and related G protein signaling $[13,32,33]$.

\section{SNX-PXA-RGS-PXC Subfamily in Receptor Signaling}

Similar to the canonical RGS proteins [34], the RGS domain in this subfamily functions as a GAP module, which potentially attenuates GPCR signaling (Table $3[13,20,23,27,33$, $35,36])$. SNX13 is the first identified SNX that contains the RGS domain, which regulates signaling triggered by GPCRs [33]. Zheng et al. reported that SNX13, through its RGS domain, interacts with the constitutively active form of $\mathrm{G} \alpha \mathrm{s}$, accelerating the hydrolysis of GTP by G $\alpha$ s [33]. Exogenous expression of the RGS domain of SNX13 reduces the agonistmediated cAMP increase in HEK293 cells and adenylate cyclase activity in rat cardiac membranes [32,33], while no effect is observed on forskolin-induced cAMP production and adenylate cyclase activity [33], which does not require G $\alpha$ s. These studies confirm the role of SNX13, as a GAP, in attenuating G $\alpha$ s-mediated signaling, indicating that SNX13 plays a critical role in the regulation of the duration of GPCR signaling [32]. SNX13 and $\mathrm{D}_{1} \mathrm{R}$ may interact because $S N X 13105820 \mathrm{C}$ and DRD1 G-94 have been associated with an 
increase in albumin excretion in a twin pair study [37]. Therefore, SNX 13 may have a role in $\mathrm{D}_{1} \mathrm{R}$ signaling.

Table 3. Examples of RGS domain in SNX-PXA-RGS-PXC subfamily members.

\begin{tabular}{|c|c|c|c|c|c|c|}
\hline SNX & RGS Domain & $\begin{array}{c}\mathrm{G} \alpha \mathrm{s} \\
\text { Interaction }\end{array}$ & GAP Activity & G $\alpha$ s Signaling & $\begin{array}{c}\text { GPCR Cargo } \\
\text { Example }\end{array}$ & Reference(s) \\
\hline SNX13 & + & + & + & inhibition & $\begin{array}{l}\beta_{2}-\mathrm{AR} \\
\mathrm{EGFR}\end{array}$ & {$[33,35]$} \\
\hline SNX14 & + & + & - & inhibition & $5-\mathrm{HT}_{6} \mathrm{R}$ & [13] \\
\hline SNX19 & - & NA & NA & NA & $\mathrm{D}_{1} \mathrm{R}$ & [20] \\
\hline SNX25 & + & ND & ND & ND & $\begin{array}{c}\mathrm{D}_{1} \mathrm{R} \\
\mathrm{D}_{2} \mathrm{R} \\
\text { TGF- } \beta 1\end{array}$ & {$[23,27,36]$} \\
\hline
\end{tabular}

Abbreviations: SNX, sorting nexin; GAP, GTPase activating protein; GPCR: G protein-coupled receptor; EGFR, epithelial growth factor receptor; $A R$, adrenergic receptor; $5-H_{6} R$, serotonin receptor 6; $D_{1} R$, dopamine receptor $1 ; D_{2} R$, dopamine receptor 2; TGF- $\beta 1$, transforming growth factor $\beta 1 ;+$, Yes; -, No; NA, not applicable; ND, not determined.

The RGS domain does not have to function as a GAP to regulate GPCR signaling in all cases. For example, the RGS domain of SNX14 does not have GAP activity, but specifically binds to and sequesters $\mathrm{G} \alpha \mathrm{s}$, inhibiting the downstream cAMP production caused by the activation of serotonin receptor $6\left(5-\mathrm{HT}_{6} \mathrm{R}\right)$ [13]. The binding affinity of SNX14 for G $\alpha$ s is markedly attenuated by the phosphorylation of the RGS domain [13]. This suggests that SNX14 negatively regulates $5-\mathrm{HT}_{6} \mathrm{R}$ signaling by sequestering $\mathrm{G} \alpha \mathrm{s}$.

As discussed above, the RGS domain facilitates the SNX-PXA-RGS-PXC subfamily in the regulation of GPCR signaling by sequestering G $\alpha$ s with [33] or without [13] GAP function. To confirm further that RGS domain is not always required for SNX regulation of GPCR signaling, it is critical to study SNX19, a member of this family without RGS domain. SNX19 is essential for the lipid raft residence of $D_{1} R$, cAMP production, and promotion of effective $\mathrm{D}_{1} \mathrm{R}$ signaling [20]. SNX19 also regulates the signaling of histamine receptor $\mathrm{H} 4$ (HRH4), a GPCR that is important in the initiation and maintenance of inflammation in mouse lung, following ammonia exposure [38].

In addition to GPCRs, the SNX-PXA-RGS-PXC subfamily also regulates the signaling of non-GPCRs. In mouse insulinoma cells exposed to high glucose concentration, SNX19 inhibits the conversion of $\mathrm{PI}(4,5) \mathrm{P}_{2}$ to $\mathrm{PI}(3,4,5) \mathrm{P}_{3}$ and suppresses the phosphorylation of Akt/protein kinase $\mathrm{B}(\mathrm{PKB})$, playing critical roles in insulin receptor signaling [22]. In NIH3T3 fibroblasts, SNX25 negatively interacts with transforming growth factor- $\beta$ receptor 1 (TGF- $\beta 1$ ) and downregulates its signaling by increasing the degradation of its receptor [23]. Of note, RGS domain is not necessarily responsible for the regulation of signaling [20,23]. Deletion of either PX or PXA domain abolishes the interaction of SNX25 with TGF- $\beta 1$ and inhibits TGF- $\beta 1$ signaling [23]. However, the RGS domain is not critical for the regulation of receptor signaling in this context [23]. SNX25 may also be involved in the circadian rhythmic regulation of vasopressin secretion in the mouse suprachiasmatic nucleus [24].

\section{SNX-PXA-RGS-PXC Subfamily in Membrane Trafficking}

Upon endocytosis, receptors (GPCR or non-GPCR) are trafficked to early endosomes, and then sorted to distinct destinations: lysosomal-mediated degradation or recycling to the plasma membrane or other organelle compartments for reuse [39]. As discussed previously, the SNX-PXA-RGS-PXC subfamily has a conserved PX domain, which enables the SNX to be targeted effectively to endosomal membranes, most frequently by binding to PI(3)P [6]. Therefore, the SNX-PXA-RGS-PXC subfamily represents a core regulator for mediating receptor-endocytic membrane trafficking. 


\subsection{SNX-PXA-RGS-PXC Subfamily in Lysosomal-Mediated Degradation}

Endolysosomal trafficking is the major pathway by which transmembrane receptors are downregulated. Membrane contact sites (MCS) between lysosomes and endosomes, as well as mitochondria and endoplasmic reticulum (ER), are regions of phospholipid exchange, which regulate the sorting of receptors at late endosomes for degradation [40,41]. In yeast, $\mathrm{Mdm} 1$ (mitochondrial distribution and morphology 1), equivalent to the mammalian SNX-PXA-RGS-PXC subfamily, is a tethering protein that localizes to ER-vacuole/lysosome MCS [42]. Mdm1 PX domain is required and sufficient for its association with the vacuole/lysosome surface [42]. Overexpression of Mdm1 induces ER-vacuole/lysosome tethering and truncation of Mdm1, which removes the PXA domain, disrupts the ER-vacuole tethering, and suppresses lipid exchange and endolysosomal sorting [42].

SNX13 binds to a wide range of phosphoinositides (Table 2) and plays an important role in receptor-endosome-lysosomal degradation. In zebrafish cardiomyocytes, a reduction in SNX13 expression promotes the endolysosomal sorting of apoptosis repressor with caspase recruitment domain (ARC) for its lysosomal degradation [12]. SNX13 interacts with ARC and regulates the interaction between ARC and caspase-8. The increase in the lysosomal degradation of ARC results in the removal of ARC-mediated inhibition and the activation of caspase-8, leading to the activation of the extrinsic apoptotic pathway and subsequent apoptotic cardiomyocyte death [12]. In HEK293 cells, overexpression of SNX13 delays the ligand-dependent EGFR lysosomal targeting, trafficking, and degradation [33],

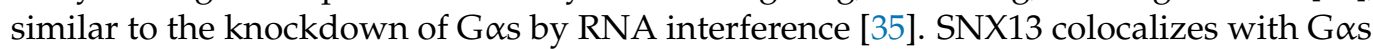
and hepatocyte growth factor-regulated tyrosine kinase substrate (Hrs) [35], a critical component of the endosomal sorting machinery for sequestration into multivesicular bodies and subsequent degradation in lysosomes [43]. Henceforth, SNX13 effectively promotes EGFR lysosomal degradation.

Morphological evidence also demonstrated the critical role of SNX13 in lysosomal degradation. Two distinct endosome morphologies, vesicular and tubular, are involved in receptor degradation and recycling pathways, respectively [44]. An unusually abundant amount of tubular endosome structures was observed in the visceral yolk sac endoderm cells of systemic Snx13-null mice [45]. This indicates that the receptor is rerouted from endosomes to recycling or TGN pathways due to the defect in the sorting of the lysosomal pathway from early endosomes caused by the knockout of SNX13.

The SNX14 PX domain preferentially binds to $\mathrm{PI}(3,5) \mathrm{P}_{2}[16]$, a key component of late endosomes/lysosomes [9,10], implicating its role in lysosomal degradation [16]. Similar to the yeast homologue of SNX14, Mdm1, which mediates the formation of ER-vacuole contact sites [42], SNX14 tethers for ER localization through its N-terminal transmembrane helices [14]. Knockdown of SNX14 causes accumulation of aberrant cytoplasmic vacuoles, suggesting defects in endolysosomal homeostasis [14]. SNX14 localizes at the interface between the ER and lipid droplets (LDs); SNX14, overexpressed in human bone osteosarcoma epithelial cells (U2OS), mediates LD budding and growth from the ER surface, after which the LDs are released following its maturation [15]. SNX14 also interacts with 5-HT ${ }_{6} \mathrm{R}$, facilitating its endolysosomal degradation [13]. In yeast, Mdm1 not only tethers ER and LDs together, but also generates a high concentration of activated lipids proximal to the vacuole that may facilitate LDs' autophagic lysosomal degradation [46].

Knockdown of Snx19 decreases the transmembrane protein, insulinoma-associated protein 2 (IA-2), and the number of dense core vesicles (DCV) in MIN6 cells, a mouse pancreatic $\beta$-cell line. The decrease in the IA- 2 protein expression and the amount of DCV correlate with the increase in autophagic lysosomal activity [47], which is rescued with the re-introduction of SNX19, indicating a critical role of SNX19 in DCV autophagic lysosomal degradation in MIN6 cells [47].

SNX25 interacts with tropomyosin receptor kinase B (TrkB) in early endosomes, late endosomes, and lysosomes in hippocampal neurons and HEK293T cells [48]. SNX25 overexpression remarkedly reduces the expression of ligand dependent TrkB protein in 
HEK293T cells [48]. These findings suggest that SNX25 is important in the endolysosomal degradation of TrkB.

\subsection{SNX-PXA-RGS-PXC Subfamily in Membrane Recycling}

Besides mediating endolysosomal degradation, as described above [49], the SNX-PXARGS-PXC subfamily, like other SNXs, also regulates receptor membrane recycling. SNX19 plays an important role in $\mathrm{D}_{1} \mathrm{R}$ plasma membrane recycling [20]. In renal proximal tubule cells, SNX19 interacts and colocalizes with $\mathrm{D}_{1} \mathrm{R}$ at the plasma membrane, specifically in lipid rafts. This colocalization is increased by treatment with fenoldopam, a $\mathrm{D}_{1}$-like receptor agonist [20]. The increase in their colocalization starts within a few minutes and returns to the basal level after one hour [20]. Depletion of $S N X 19$ by its specific siRNA decreases $D_{1} R$ lipid raft localization, plasma membrane expression, and signaling [20]. All of these results indicate the critical role of SNX19 in $\mathrm{D}_{1} \mathrm{R}$ recycling, probably via palmitoylation and lipid raft targeting.

SNX25 interacts with $D_{1} R$ and $D_{2} R$ in HEK293 cells, and overexpression of SNX25 perturbs the endocytosis of $D_{1} R$ and $D_{2} R$ and recycling of the $D_{2} R$. Moreover, knockdown of $S N X 25$ causes a subsequent decrease in $\mathrm{D}_{2} \mathrm{R}$ plasma membrane expression, suggesting that $\mathrm{SNX} 25$ plays a role in $\mathrm{D}_{2} \mathrm{R}$ membrane recycling [27].

\section{Comparison of SNX-PXA-RGS-PXC Subfamily with SNX-BAR Subfamily in Receptor Signaling and Membrane Trafficking}

SNX-BAR, another subfamily of SNXs, is known to regulate receptor signaling and orchestrate membrane trafficking through distinct mechanisms. Although there are few overlaps with the SNX-PXA-RGS-PXC subfamily, the SNX-BAR sorting nexin subfamily regulates different types of receptor cargoes. For example, SNX1 is important for $\mathrm{D}_{5} \mathrm{R}$ signaling [50], while the SNX5 regulates the signaling and trafficking of $D_{1} R$ [51], insulin receptors [52], and insulin-degrading enzyme [53] in renal proximal tubule cells. Likewise, SNX1, SNX2, and SNX6 have been found to regulate the membrane trafficking of cation-independent mannose phosphate receptor (CI-MPR) [54,55], cell surface receptor CED-1 [56], TGN38 [57], vacuolar sorting receptor [58], $\beta$-site amyloid precursor proteincleaving enzyme 1 (BACE1) [59], PIN1 [60], and PIN2 [60]. SNX4 regulates the transferrin receptor [61], BACE1 [62], and E-cadherin recycling [63]. SNX18 regulates the transfer of LC3 from the recycling endosome to the autophagosome [64].

Distinct from the SNX-PXA-RGS-PXC subfamily, the SNX-BAR subfamily shares a close relationship with retromers and other retrieval machineries. SNX-BAR subfamily contains a dimeric Bin-Amphiphysin-Rvs (BAR) domain with a positively charged curved surface that binds to membranes [65]. The BAR domain confers targeting to the tubular domain of the endosome, and the endosome aids the transition from a spherical vacuole to a tubule membrane through the interaction of the BAR domains with endosomes, forming a tubular transport carrier [7]. In yeast, the SNX-BAR dimer forms a stable complex with the retromer, a heterotrimer of Vps26-Vps29-Vps35 [65]. In mammalian cells, the association of SNX-BAR dimer with the retromer is relatively weak, but SNX-BAR still relies on the retromer to orchestrate the recognition and capture of specific cargoes [2,3]. The weak association of SNX-BAR with the retromer in mammalian cells may reflect the large diversity of cargoes and the need for other proteins, such as Rab GTPases [66, 67], ubiquitin [68], actin filaments [67], and WASH complex [69], to coordinate in the regulation of receptor signaling and trafficking $[3,7]$. The retromer is also critical for SNXBAR regulation of receptor endocytic trafficking, retromer-independent receptor plasma membrane recycling, and endosome-to-TGN retrograde trafficking $[61,70,71]$. Because the SNX-PXA-RGS-PXC subfamily lacks the BAR domain, it does not depend on the retromer or other retrieval machineries to regulate receptor cargo signaling and trafficking.

Different from SNX-BAR, the SNX-PXA-RGS-PXC subfamily (except SNX19) plays some roles similar to RGS proteins. Canonical RGS proteins regulate the signaling of their GPCR cargo, by binding directly to G $\alpha$ s, and function as a GAP [72]. SNX13, like canonical RGS proteins, can function as a GAP [34], but more studies are needed to 
determine if this function extends to all members of this subfamily of SNXs, i.e., SNXPXA-RGS-PXC. As aforementioned, $\mathrm{D}_{1} \mathrm{R}$ signaling is regulated by SNX5, a member of SNX-BAR without the RGS domain. Both SNX5 and SNX19 regulate $D_{1} R$ internalization in early endosomes $[20,51]$. It is unknown whether the two $S N X_{\text {s regulate }} D_{1} R$ subsequent trafficking and lysosomal degradation. SNX5 and SNX19 differently regulate $\mathrm{D}_{1} \mathrm{R}$ recycling (Figure 2).

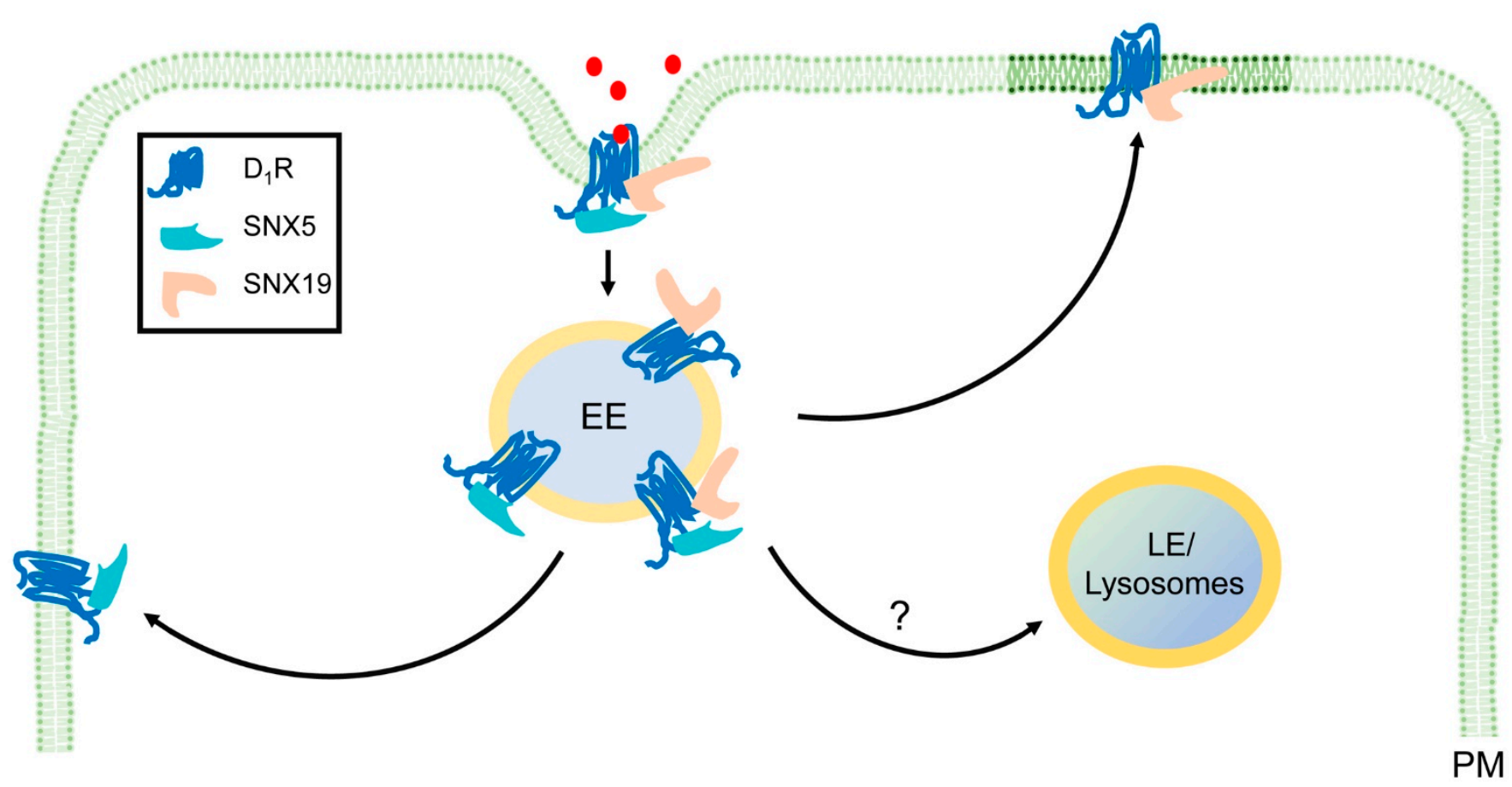

Figure 2. Regulation of $\mathrm{D}_{1} \mathrm{R}$ signaling and membrane trafficking by SNX5 and SNX19 in human renal proximal tubule cells. $D_{1} R$ is stimulated by dopamine or $D_{1} R$ agonists, resulting in the activation of $G \alpha$ s and increase in $C$ AMP production (not shown). Both SNX5 and SNX19 interact to internalize $\mathrm{D}_{1} \mathrm{R}$ in early endosomes (EE). It is not clear if SNX5 and SNX19 participate in the subsequent trafficking of $D_{1} R$ in late endosomes (LE) and lysosomes. SNX5 and SNX19 differently regulate $\mathrm{D}_{1} \mathrm{R}$ recycling; $\mathrm{SNX} 5$ may regulate $\mathrm{D}_{1} \mathrm{R}$ recycling through phosphorylation (not shown), while SNX19 regulates $D_{1} R$ recycling through palmitoylation and targeting $D_{1} R$ to lipid rafts (dark green). Red dots, dopamine, fenoldopam, or other $\mathrm{D}_{1} \mathrm{R}$ agonists.

SNX5 regulates $D_{1} R$ signaling, probably through $G$ protein-coupled receptor kinase (GRK) 4-mediated phosphorylation and desensitization of $D_{1} R$, but not by targeting $D_{1} R$ to lipid rafts [51]. As previously stated, SNX19, a member of the SNX-PXA-RGS-PXC subfamily without the RGS domain, is required for the $\mathrm{D}_{1} \mathrm{R}$-stimulated cAMP production [20]. Therefore, the RGS domain and its GAP function are not essential for the regulation of GPCR signaling by SNX19. SNX19 interacts with the Golgi-associated DHHC-type zinc finger enzyme for $D_{1} R$ palmitoylation and targeting into lipid rafts, where adenylate cyclase 6 is located [8], to regulate $\mathrm{D}_{1} \mathrm{R}$ signaling [20]. How SNX5 and SNX19, individually or synergistically regulate $D_{1} R$ signaling and internalization and if they regulate the degradation of $D_{1} R$ in lysosomes remains to be determined.

In contrast to the SNX-BAR subfamily, the SNX-PXA-RGS-PXC subfamily has a different preference for trafficking routes for its receptor cargoes. Based on recent limited studies, the SNX-PXA-RGS-PXC subfamily mainly transports receptor cargoes, via the endolysosomal pathway for degradation $[12,16,35,42,43,45]$, while the SNX-BAR family mainly retrieves cargoes away from lysosomal degradation, via recycling pathways from the endosome to the plasma membrane, or retrograde pathways from the endosometo-TGN [2-8,73-75]. The different trafficking pathways could be due to the distinct mi- 
crodomain localization of retrieval machineries (e.g., retromers) for retrieval of receptor cargoes from ESCRT (endosomal sorting complex required for transport proteins) for degradation, as demonstrated in the Caenorhabditis elegans coelomocyte $[76,77]$. Whether a particular receptor cargo is sorted for recycling or endosomal degradation is governed largely by the SNX associated with retrieval complexes or the ESCRT machinery [2,3,5]. It is plausible for SNX-BAR family to regulate plasma membrane recycling or retrograde trafficking from endosomes to TGN through the retromer-dependent or retromer-independent (e.g.,: ESCPE-1, endosomal SNX-BAR sorting complex for promoting exit-1) protein machineries $[69,78]$. Ubiquitination $[79,80]$ and palmitoylation $[81,82]$ are important mechanisms for receptor cargo sorting into the ESCRT-mediated degradation. The $\mathrm{D}_{1} \mathrm{R}$ is regulated by ubiquitination [83] and palmitoylation [20], and as aforementioned, SNX5 [51] and SNX19 [20] regulate $D_{1} R$ signaling and trafficking. Therefore, it is possible that ubiquitin-tagged or palmitoylated $\mathrm{D}_{1} \mathrm{R}$ is sequestered by different ESCRT-subunits, using distinct mechanisms for its lysosomal degradation [84].

\section{Comparison of SNX-PXA-RGS-PXC Subfamily with Other SNX Subfamilies}

The SNX-PXA-RGS-PXC subfamily has differences from the other SNX subfamilies in its role in receptor signaling and trafficking. For example, SNX3, a member of the SNX-PX subfamily, interacts with the retromer complex to regulate cargoes, such as the divalent metal transporter 1-II (DMT1-II) recycling from the endosome to TGN [85]. SNX17, a member of the SNX-FERM subfamily, interacts via its FERM domain with cargoes, such as integrins, for endosomal recycling to the plasma membrane [86]. During this process, SNX17 is associated with the Commander complex, an assembly comprised of at least fifteen proteins, including the retriever, a retromer-like structure, consisting of three proteins VPS35L, VPS26C, and VPS29 [87]. SNX27, another member of the SNX-FERM subfamily, interacts simultaneously, via its unique PDZ domain, with retromer subunit and cargo receptors, such as the $\beta_{2} \mathrm{AR}$, to regulate their recycling [88].

\section{SNX-PXA-RGS-PXC Subfamily in Physiology and Pathophysiology}

As aforementioned, the SNX-PXA-RGS-PXC subfamily regulates the signaling and trafficking of internalized cargoes, including GPCRs and non-GPCRs, mainly leading them to endolysosomal degradation $[10,13,42]$. There is a dynamic coordinated interaction among the recycling, retrograde, and degradative pathways, which maintains normal cellular functions [2,3]. However, if the SNX-PXA-RGS-PXC subfamily, like all other SNX subfamilies, is dysfunctional and disabled to transport receptor cargoes to their appropriate cellular destinations, there will be the impairment of the above-mentioned pathways, which will negatively affect cellular functions, causing disorders, such as those listed in Table 4 [17-20,23,27,33,38,89-98].

SNX13 forms a heterotrimeric complex with G $\alpha$ s and Hrs in endosomes, critical in targeting ubiquitinated membrane cargoes, such as EGFR, for sequestration into multivesicular bodies and subsequent degradation in lysosomes [35,42]. Germline deletion of Snx13 in mice is embryonically lethal, indicating that SNX13-regulated endocytosis dynamics is essential in mouse development [45]. SNX13 plays a crucial role in preserving cardiomyocyte survival by targeting ARC endolysosomal degradation [12]. SNX13 is associated with skin pigmentation variation in humans $[89,99]$, indicating that SNX13 plays a role in melanin cellular transport and trafficking.

SNX14 is important in normal neuronal excitability and synaptic transmission [90]. SNX14, localized in the lysosome [16], functions as a negative regulator of the signaling and trafficking of 5- $\mathrm{HT}_{6} \mathrm{R}$ [13] and probably other receptor cargoes, as well. SNX14 is also localized at the membrane contact site of ER-lipid droplets in yeast, drosophila, and mammals $[14,42,91,100]$, indicating important roles of SNX14 in lipid drop biogenesis and trafficking of lipid transfer proteins [101]. 
Table 4. SNX-PXA-RGS-PXC subfamily in cellular physiology and implications in diseases.

\begin{tabular}{|c|c|c|c|c|}
\hline Subfamily & Signaling & Trafficking Function & Disease Links & References \\
\hline SNX13 & G $\alpha$ s inhibition & Lysosomal degradation & $\begin{array}{c}\text { Saethre-Chotzen syndrome phenotype } \\
\text { Type } 2 \text { diabetes } \\
\text { Skin pigmentation }\end{array}$ & {$[33,35,89,95,96]$} \\
\hline SNX14 & $\begin{array}{l}\text { cAMP/PKA } \\
\text { inhibition }\end{array}$ & Lysosomal degradation & $\begin{array}{c}\text { SCAR20 } \\
\text { Neuron development and } \\
\text { differentiation } \\
\text { Microcephaly } \\
\text { Down syndrome } \\
\text { Cerebellar ataxia } \\
\text { Intellectual disability } \\
\text { Congenital disorders of autophagy } \\
\text { Squamous cell carcinoma }\end{array}$ & {$[17,90,91,97]$} \\
\hline SNX19 & $\begin{array}{c}\text { Palmitoylation } \\
\text { Akt/PKB }\end{array}$ & $\begin{array}{l}\text { Lipid raft targeting } \\
\text { Lysosomal degradation } \\
\text { Recycling }\end{array}$ & $\begin{array}{l}\text { Hypertension } \\
\text { Type I diabetes } \\
\text { Atherosclerosis } \\
\text { Schizophrenia }\end{array}$ & {$[18-20,23,92,98]$} \\
\hline SNX25 & $\begin{array}{c}\text { TGF } \beta \text {-SMAD } \\
\text { phosphorylation? }\end{array}$ & Lysosomal degradation & $\begin{array}{c}\text { Temporal lobe epilepsy } \\
\text { dHMN } \\
\text { LOAD } \\
\text { EOAD } \\
\text { Hypertension }\end{array}$ & {$[25-27,94]$} \\
\hline
\end{tabular}

Abbreviations: SNX, sorting nexin; Akt/PKB, protein kinase B; cAMP/PKA, cyclic adenosine monophosphate/Protein Kinase A; TGF $\beta$ SMAD, transforming growth factor beta-ALK5-Sma- and Mad-related protein; dHMN, distal hereditary motor neuropathy; EOAD, early-onset Alzheimer's Disease; LOAD, late-onset Alzheimer's Disease; SCAR20, Autosomal Recessive Spinocerebellar Ataxia 20.

SNX19 interacts with $\mathrm{D}_{1} \mathrm{R}$ and Golgi-associated DHHC-type zinc finger [20], a palmitoyltransferase in Golgi [102] and, as previously stated, facilitates $\mathrm{D}_{1} \mathrm{R}$ palmitoylation, trafficking from anterograde trafficking, and recycling [20]. This promotes the residence of $\mathrm{D}_{1} \mathrm{R}$ in the lipid rafts [20], where other $\mathrm{D}_{1} \mathrm{R}$ signaling complex components are localized, including GRK4, G proteins, adenylyl cyclases, and effector proteins, such as NADPH oxidase, $\mathrm{Na}^{+}-\mathrm{K}^{+}$-ATPase, and $\mathrm{Na}^{+}-\mathrm{H}^{+}$exchanger (NHE) 3, for appropriate cellular responses and functions [103-106]. The PX domain of SNX19 is required for $\mathrm{D}_{1} \mathrm{R}$ targeting to lipid rafts because the deletion of the PX domain results in the $\mathrm{D}_{1} \mathrm{R}$ mistargeting to non-lipid rafts [20]. Moreover, SNX19 knockdown not only decreases the $\mathrm{D}_{1} \mathrm{R}$-induced increase in cAMP production, but also abrogates the ability of the $\mathrm{D}_{1} \mathrm{R}$ to inhibit renal tubular sodium reabsorption [20]. Importantly, renal Snx19 knockdown increases the systolic blood pressure of C57BL/6J mice [20], indicating critical roles of SNX19 on the regulation of blood pressure. SNX19 also interacts with Islet antigen-2 [92], a major autoantigen in type 1 diabetes, and is located in dense-core secretory vesicles that regulate insulin secretion [23]. SNX19 may function as a protective factor against cartilage degradation [21]. A single nucleotide polymorphism of SNX19, rs2298566, increases the risk of coronary heart disease [18].

SNX25 is involved in the lysosomal degradation of the TGF- $\beta$ receptor [23] and the development of temporal lobe epilepsy [25]. SNX25 interacts with and accelerates tropomyosin-related kinase B degradation [48]. SNX25 may also be involved in the regulation of genes associated with mesothelioma [93]. SNX25 is a potential candidate gene for distal hereditary motor neuropathies [94] and a genetic modifier of the age of onset of familial Alzheimer's disease [26].

\section{Conclusions and Perspectives}

Emerging evidence has demonstrated that the SNX-PXA-RGS-PXC subfamily and their interacting partners are critical regulators for receptor signaling and membrane trafficking. The receptor cargoes can be GPCRs and non-GPCRs through which cells respond to 
both extracellular and intracellular stimulation. The complex interaction between cellular signaling and endosomal-based membrane trafficking plays an essential role in maintaining cellular homeostasis and versatile functions. SNX13, 14, and 25 have a unique RGS domain, which presumably serves as GAP, attenuating signals associated with GPCR. It is important to examine the molecular mechanisms of GAP both in vitro and in vivo for all three SNXs of the above subfamily. Current evidence suggests that SNX 19 lacks an RGS domain, indicating that it is unable to serve as a GAP. However, SNX19 has emerged to regulate GPCR in other ways, for example, facilitating $\mathrm{D}_{1} \mathrm{R}$ signaling through palmitoylation. Further studies are needed to determine the precise molecular mechanisms by which SNX19 regulates palmitoylation in the Golgi and the plasma membrane.

Different from retromer-dependent SNXs, which retrieve their cargoes through recycling to plasma membrane, TGN or other organelles in retromer-dependent and independent mechanisms, the SNX-PXA-RGS-PXC subfamily mainly regulates their cargo receptors for endolysosomal degradation. The SNX-PXA-RGS-PXC subfamily regulates receptor recycling for certain cargoes as well, but the molecular switch that controls the different post-endocytic trafficking routes remains to be identified.

While cellular signaling directs the distinct receptor cargo trafficking routes, cargo trafficking actively shapes the cellular signaling response as well, by altering the location and time of specific signaling events. The incomplete understanding of the role that RGSPXC SNX plays in cell polarity warrants further research. For example, it is important to understand the exact function of the SNX-PXA-RGS-PXC subfamily in the sorting of $\mathrm{D}_{1} \mathrm{R}$ and renal sodium transporters to different cell surface domains. We need to study how such processes can control polarized apical and basolateral locations and cellular function for sodium transport in the renal proximal tubule and other nephron segments. It is expected that the SNX-PXA-RGS-PXC subfamily, as with other SNXs, plays diverse roles on the regulation of the intricately linked signaling and trafficking for precise cellular functional outputs. Studies in appropriate conditional or non-conditional global knockout and transgenic or gene rescue animal models will advance our understanding of the physiological functions in vivo of the SNX-PXA-RGS-PXC subfamily and their associated pathophysiological disorders, which could lead to potential novel therapies targeting this SNX subfamily.

Author Contributions: B.A., H.L. and P.A.J. wrote the manuscript; B.A., H.L. and P.A.J. prepared the figures and tables. All authors (B.A., H.L., L.D.A., P.K., I.A., R.A.F., P.A.J.) edited and revised the manuscript and approved its final version. All authors have read and agreed to the published version of the manuscript.

Funding: The work was funded by grants from the US National Institutes of Health R01DK119652, R37HL023081, R01DK039308, R01HL092196, R01DK090918, P01HL068686, P01HL074940, and U01GM074492.

Conflicts of Interest: The authors declare no conflict of interest.

\section{Abbreviations}

$\begin{array}{ll}\text { Akt/PKB } & \text { protein kinase B } \\ \text { AR } & \text { adrenergic receptor } \\ \text { ARC } & \text { apoptosis receptor with caspase recruitment domain } \\ \text { BACE 1 } & \beta \text {-site amyloid precursor protein-cleaving enzyme 1 } \\ \text { BAR } & \text { Bin-Amphiphysin-Rvs } \\ \text { cAMP/PKA } & \text { cyclic adenosine monophosphate/protein kinase A } \\ \text { CED-1 } & \text { cell death abnormality protein-1 }\end{array}$




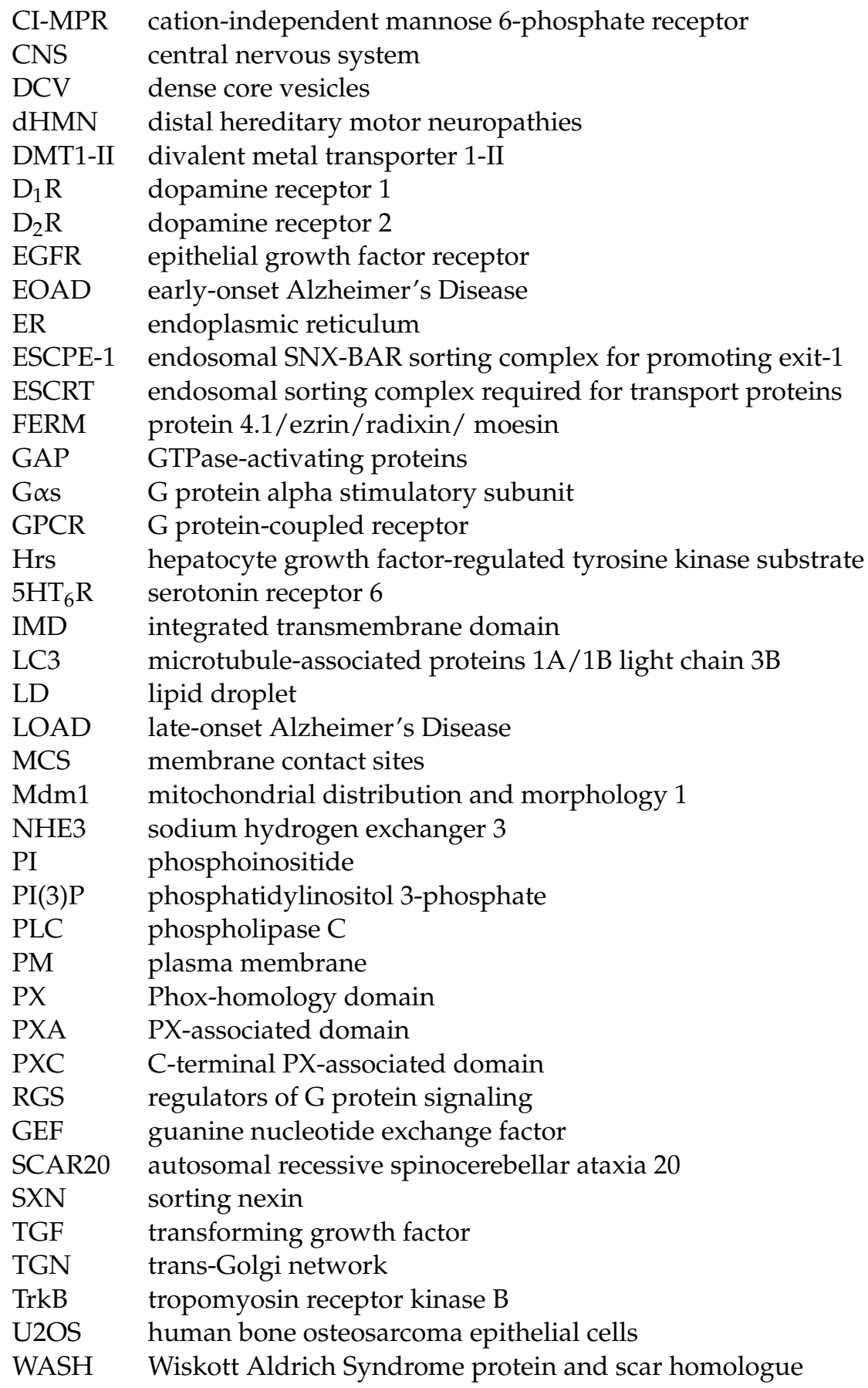

\section{References}

1. Lobingier, B.T.; von Zastrow, M. When trafficking and signaling mix: How subcellular location shapes G protein-coupled receptor activation of heterotrimeric G proteins. Traffic 2019, 20, 130-136. [CrossRef]

2. Wang, J.; Fedoseienko, A.; Chen, B.; Burstein, E.; Jia, D.; Billadeau, D.D. Endosomal receptor trafficking: Retromer and beyond. Traffic 2018, 19, 578-590. [CrossRef] [PubMed]

3. Naslavsky, N.; Caplan, S. The enigmatic endosome-sorting the ins and outs of endocytic trafficking. J. Cell Sci. 2018, 131, jcs216499. [CrossRef] [PubMed]

4. Chandra, M.; Collins, B.M. The phox homology (PX) domain. Adv. Exp. Med. Biol. 2019, 1111, 1-17. [PubMed]

5. Cullen, P.J.; Korswagen, H.C. Sorting nexins provide diversity for retromer-dependent trafficking events. Nat. Cell Biol. 2012, 14, 29-37. [CrossRef] [PubMed]

6. Teasdale, R.D.; Collins, B.M. Insights into the PX (phox-homology) domain and SNX (sorting nexin) protein families: Structures, functions and roles in disease. Biochem. J. 2012, 441, 39-59. [CrossRef]

7. Gallon, M.; Cullen, P.J. Retromer and sorting nexins in endosomal sorting. Biochem. Soc. Trans. 2015, 43, 33-47. [CrossRef] 
8. Yang, J.; Villar, V.A.M.; Rozyyev, S.; Jose, P.A.; Zeng, C. The emerging role of sorting nexins in cardiovascular diseases. Clin. Sci. 2019, 133, 723-737. [CrossRef]

9. Falasca, M.; Maffucci, T. Rethinking phosphatidylinositol 3-monophosphate. Biochim. Biophys. Acta 2009, 1793, 1795-1803. [CrossRef]

10. Mas, C.; Norwood, S.J.; Bugarcic, A.; Kinna, G.; Leneva, N.; Kovtun, O.; Ghai, R.; Ona Yanez, L.E.; Davis, J.L.; Teasdale, R.D.; et al. Structural basis for different phosphoinositide specificities of the PX domains of sorting nexins regulating G-protein signaling. J. Biol. Chem. 2014, 289, 28554-28568. [CrossRef] [PubMed]

11. Chandra, M.; Chin, Y.K.; Mas, C.; Feathers, J.R.; Paul, B.; Datta, S.; Chen, K.E.; Jia, X.; Yang, Z.; Norwood, S.J.; et al. Classification of the human phox homology (PX) domains based on their phosphoinositide binding specificities. Nat. Commun. 2019, 10, 1528. [CrossRef]

12. Li, J.; Li, C.; Zhang, D.; Shi, D.; Qi, M.; Feng, J.; Yuan, T.; Xu, X.; Liang, D.; Xu, L.; et al. SNX13 reduction mediates heart failure through degradative sorting of apoptosis repressor with caspase recruitment domain. Nat. Commun. 2014, 5, 5177. [CrossRef]

13. Ha, C.M.; Park, D.; Kim, Y.; Na, M.; Panda, S.; Won, S.; Kim, H.; Ryu, H.; Park, Z.Y.; Rasenick, M.M.; et al. SNX14 is a bifunctional negative regulator for neuronal 5-HT6 receptor signaling. J. Cell Sci. 2015, 128, 1848-1861. [CrossRef]

14. Bryant, D.; Liu, Y.; Datta, S.; Hariri, H.; Seda, M.; Anderson, G.; Peskett, E.; Demetriou, C.; Sousa, S.; Jenkins, D.; et al. SNX14 mutations affect endoplasmic reticulum-associated neutral lipid metabolism in autosomal recessive spinocerebellar ataxia 20. Hum. Mol. Genet. 2018, 27, 1927-1940. [CrossRef] [PubMed]

15. Datta, S.; Liu, Y.; Hariri, H.; Bowerman, J.; Henne, W.M. Cerebellar ataxia disease-associated Snx14 promotes lipid droplet growth at ER-droplet contacts. J. Cell Biol. 2019, 218, 1335-1351. [CrossRef] [PubMed]

16. Akizu, N.; Cantagrel, V.; Zaki, M.S.; Al-Gazali, L.; Wang, X.; Rosti, R.O.; Dikoglu, E.; Gelot, A.B.; Rosti, B.; Vaux, K.K.; et al. Biallelic mutations in SNX14 cause a syndromic form of cerebellar atrophy and lysosome-autophagosome dysfunction. Nat. Genet. 2015, 47, 528-534. [CrossRef]

17. Thomas, A.C.; Williams, H.; Setó-Salvia, N.; Bacchelli, C.; Jenkins, D.; O’Sullivan, M.; Mengrelis, K.; Ishida, M.; Ocaka, L.; Chanudet, E.; et al. Mutations in SNX14 cause a distinctive autosomal-recessive cerebellar ataxia and intellectual disability syndrome. Am. J. Hum. Genet. 2014, 95, 611-621. [CrossRef]

18. Bare, L.A.; Morrison, A.C.; Rowland, C.M.; Shiffman, D.; Luke, M.M.; Iakoubova, O.A.; Kane, J.P.; Malloy, M.J.; Ellis, S.G.; Pankow, J.S.; et al. Five common gene variants identify elevated genetic risk for coronary heart disease. Genet. Med. 2007, 9, 682-689. [CrossRef]

19. Fullard, J.F.; Giambartolomei, C.; Hauberg, M.E.; Xu, K.; Voloudakis, G.; Shao, Z.; Bare, C.; Dudley, J.T.; Mattheisen, M.; Robakis, N.K.; et al. Open chromatin profiling of human postmortem brain infers functional roles for non-coding schizophrenia loci. Hum. Mol. Genet. 2017, 26, 1942-1951. [CrossRef] [PubMed]

20. Tiu, A.C.; Yang, J.; Asico, L.D.; Konkalmatt, P.; Zheng, X.; Cuevas, S.; Wang, X.; Lee, H.; Mazhar, M.; Felder, R.A.; et al. Lipid rafts are required for effective renal D1 dopamine receptor function. FASEB J. 2020, 34, 6999-7017. [CrossRef]

21. Kan, A.; Ikeda, T.; Saito, T.; Yano, F.; Fukai, A.; Hojo, H.; Ogasawara, T.; Ogata, N.; Nakamura, K.; Chung, U.I.; et al. Screening of chondrogenic factors with a real-time fluorescence-monitoring cell line ATDC5-C2ER: Identification of sorting nexin 19 as a novel factor. Arthritis Rheum. 2009, 60, 3314-3323. [CrossRef] [PubMed]

22. Harashima, S.I.; Harashima, C.; Nishimura, T.; Hu, Y.; Notkins, A.L. Overexpression of the autoantigen IA-2 puts beta cells into a pre-apoptotic state: Autoantigen-induced, but non-autoimmune-mediated, tissue destruction. Clin. Exp. Immunol. 2007, 150, 49-60. [CrossRef]

23. Hao, X.; Wang, Y.; Ren, F.; Zhu, S.; Ren, Y.; Jia, B.; Li, Y.P.; Shi, Y.; Chang, Z. SNX25 regulates TGF- $\beta$ signaling by enhancing the receptor degradation. Cell Signal. 2011, 23, 935-946. [CrossRef]

24. Takemura, S.; Nagano, M.; Isonishi, A.; Tanaka, T.; Tatsumi, K.; Yamano, M.; Minami, Y.; Shigeyoshi, Y.; Wanaka, A. Circadian rhythms of sorting nexin 25 in the mouse suprachiasmatic nucleus. Neurosci. Lett. 2020, 727, 134897. [CrossRef]

25. Du, Y.; Zou, Y.; Yu, W.; Shi, R.; Zhang, M.; Yang, W.; Duan, J.; Deng, Y.; Wang, X.; Lü, Y. Expression pattern of sorting Nexin 25 in temporal lobe epilepsy: A study on patients and pilocarpine-induced rats. Brain Res. 2013, 1509, 79-85. [CrossRef] [PubMed]

26. Lee, J.H.; Cheng, R.; Vardarajan, B.; Lantigua, R.; Reyes-Dumeyer, D.; Ortmann, W.; Graham, R.R.; Bhangale, T.; Behrens, T.W.; Medrano, M.; et al. Genetic modifiers of age at onset in carriers of the G206A mutation in PSEN1 with Familial Alzheimer Disease among Caribbean Hispanics. JAMA Neurol. 2015, 72, 1043-1051. [CrossRef]

27. Free, R.B.; Namkung, Y.; Hazelwood, L.A.; Sibley, D.R. Sorting nexin-25 interacts with D1 and D2 dopamine receptors to regulate receptor expression and signaling. FASEB J. 2010, 24, 771-778.

28. Tesmer, J.J. Structure and function of regulator of G protein signaling homology domains. Prog. Mol. Biol. Transl. Sci. 2009, 86, 75-113.

29. Squires, K.E.; Montañez-Miranda, C.; Pandya, R.R.; Torres, M.P.; Hepler, J.R. Genetic analysis of rare human variants of regulators of $G$ protein signaling proteins and their role in human physiology and disease. Pharmacol. Rev. 2018, 70, 446-474. [CrossRef] [PubMed]

30. Willars, G.B. Mammalian RGS proteins: Multifunctional regulators of cellular signalling. Semin. Cell Dev. Biol. 2006, 17, 363-376. [CrossRef] [PubMed]

31. Stewart, A.; Fisher, R.A. Introduction: G protein-coupled receptors and RGS proteins. Prog. Mol. Biol. Transl. Sci. $2015,133,1-11$. [PubMed] 
32. Worby, C.A.; Dixon, J.E. Sorting out the cellular functions of sorting nexins. Nat. Rev. Mol. Cell Biol. 2002, 3, 919-931. [CrossRef] [PubMed]

33. Zheng, B.; Ma, Y.C.; Ostrom, R.S.; Lavoie, C.; Gill, G.N.; Insel, P.A.; Huang, X.Y.; Farquhar, M.G. RGS-PX1, a GAP for G $\alpha$ s and sorting nexin in vesicular trafficking. Science 2001, 294, 1939-1942. [CrossRef]

34. Ross, E.M.; Wilkie, T.M. GTPase-activating proteins for heterotrimeric G proteins: Regulators of G protein signaling (RGS) and RGS-like proteins. Annu. Rev. Biochem. 2000, 69, 795-827. [CrossRef]

35. Zheng, B.; Lavoie, C.; Tang, T.D.; Ma, P.; Meerloo, T.; Beas, A.; Farquhar, M.G. Regulation of epidermal growth factor receptor degradation by heterotrimeric G $\alpha$ s protein. Mol. Biol. Cell 2004, 15, 5538-5550. [CrossRef]

36. Su, K.; Xu, T.; Yu, Z.; Zhu, J.; Zhang, Y.; Wu, M.; Xiong, Y.; Liu, J.; Xu, J. Structure of the PX domain of SNX25 reveals a novel phospholipid recognition model by dimerization in the PX domain. FEBS Lett. 2017, 591, 2011-2018. [CrossRef]

37. Rao, F.; Wessel, J.; Wen, G.; Zhang, L.; Rana, B.K.; Kennedy, B.P.; Greenwood, T.A.; Salem, R.M.; Chen, Y.; Khandrika, S.; et al. Renal albumin excretion: Twin studies identify influences of heredity, environment, and adrenergic pathway polymorphism. Hypertension 2007, 49, 1015-1031. [CrossRef] [PubMed]

38. Bein, K.; Ganguly, K.; Martin, T.M.; Concel, V.J.; Brant, K.A.; Di, Y.P.; Upadhyay, S.; Fabisiak, J.P.; Vuga, L.J.; Kaminski, N.; et al. Genetic determinants of ammonia-induced acute lung injury in mice. Am. J. Physiol. Lung Cell Mol. Physiol. 2020, in press. [CrossRef] [PubMed]

39. Irannejad, R.; Tsvetanova, N.G.; Lobingier, B.T.; von Zastrow, M. Effects of endocytosis on receptor-mediated signaling. Curr. Opin. Cell Biol. 2015, 35, 137-143. [CrossRef]

40. Ballabio, A.; Bonifacino, J.S. Lysosomes as dynamic regulators of cell and organismal homeostasis. Nat. Rev. Mol. Cell Biol. 2020, 21, 101-118. [CrossRef] [PubMed]

41. Ebner, M.; Koch, P.A.; Haucke, V. Phosphoinositides in the control of lysosome function and homeostasis. Biochem. Soc. Trans. 2019, 47, 1173-1185. [CrossRef] [PubMed]

42. Henne, W.M.; Zhu, L.; Balogi, Z.; Stefan, C.; Pleiss, J.A.; Emr, S.D. Mdm1/Snx13 is a novel ER-endolysosomal interorganelle tethering protein. J. Cell Biol. 2015, 210, 541-551. [CrossRef] [PubMed]

43. Bache, K.G.; Brech, A.; Mehlum, A.; Stenmark, H. Hrs regulates multivesicular body formation via ESCRT recruitment to endosomes. J. Cell Biol. 2003, 162, 435-442. [CrossRef]

44. Klumperman, J.; Raposo, G. The complex ultrastructure of the endolysosomal system. Cold Spring Harb. Perspect Biol. 2014, 6, a016857. [CrossRef]

45. Zheng, B.; Tang, T.; Tang, N.; Kudlicka, K.; Ohtsubo, K.; Ma, P.; Marth, J.D.; Farquhar, M.G.; Lehtonen, E. Essential role of RGS-PX1/sorting nexin 13 in mouse development and regulation of endocytosis dynamics. Proc. Natl. Acad. Sci. USA 2006, 103, 16776-16781. [CrossRef]

46. Hariri, H.; Speer, N.; Bowerman, J.; Rogers, S.; Fu, G.; Reetz, E.; Datta, S.; Feathers, J.R.; Ugrankar, R.; Nicastro, D.; et al. Mdm1 maintains endoplasmic reticulum homeostasis by spatially regulating lipid droplet biogenesis. J. Cell Biol. 2019, 218, 1319-1334. [CrossRef] [PubMed]

47. Harashima, S.; Horiuchi, T.; Wang, Y.; Notkins, A.L.; Seino, Y.; Inagaki, N. Sorting nexin 19 regulates the number of dense core vesicles in pancreatic $\beta$-cells. J. Diabetes Investig. 2012, 3, 52-61. [CrossRef] [PubMed]

48. Takemura, S.; Isonishi, A.; Tanaka, T.; Okuda, H.; Tatsumi, K.; Yamano, M.; Wanaka, A. Neural expression of sorting nexin 25 and its regulation of tyrosine receptor kinase B trafficking. Brain Struct. Funct. 2020, 225, 2615-2642. [CrossRef]

49. Weeratunga, S.; Paul, B.; Collins, B.M. Recognising the signals for endosomal trafficking. Curr. Opin. Cell Biol. 2020, 65, 17-27. [CrossRef]

50. Villar, V.A.; Jones, J.E.; Armando, I.; Asico, L.D.; Escano, C.S., Jr.; Lee, H.; Wang, X.; Yang, Y.; Pascua-Crusan, A.M.; Palmes-Saloma, C.P.; et al. Sorting nexin 1 loss results in D5 dopamine receptor dysfunction in human renal proximal tubule cells and hypertension in mice. J. Biol. Chem. 2013, 288, 152-163. [CrossRef]

51. Villar, V.A.; Armando, I.; Sanada, H.; Frazer, L.C.; Russo, C.M.; Notario, P.M.; Lee, H.; Comisky, L.; Russell, H.A.; Yang, Y.; et al. Novel role of sorting nexin 5 in renal $\mathrm{D}(1)$ dopamine receptor trafficking and function: Implications for hypertension. FASEB J. 2013, 27, 1808-1819. [CrossRef]

52. Li, F.; Yang, J.; Jones, J.E.; Villar, V.A.; Yu, P.; Armando, I.; Felder, R.A.; Jose, P.A. Sorting nexin 5 and dopamine D1 receptor regulate the expression of the insulin receptor in human renal proximal tubule cells. Endocrinology 2015, 156, 2211-2221. [CrossRef] [PubMed]

53. Li, F.; Yang, J.; Villar, V.A.M.; Asico, L.D.; Ma, X.; Armando, I.; Sanada, H.; Yoneda, M.; Felder, R.A.; Jose, P.A.; et al. Loss of renal SNX5 results in impaired IDE activity and insulin resistance in mice. Diabetologia 2018, 61, 727-737. [CrossRef] [PubMed]

54. Rojas, R.; Kametaka, S.; Haft, C.R.; Bonifacino, J.S. Interchangeable but essential functions of SNX1 and SNX2 in the association of retromer with endosomes and the trafficking of mannose 6-phosphate receptors. Mol. Cell Biol. 2007, 27, 1112-1124. [CrossRef] [PubMed]

55. Mellado, M.; Cuartero, Y.; Brugada, R.; Verges, M. Subcellular localisation of retromer in post-endocytic pathways of polarised Madin-Darby canine kidney cells. Biol. Cell 2014, 106, 377-393. [CrossRef]

56. Chen, D.; Xiao, H.; Zhang, K.; Wang, B.; Gao, Z.; Jian, Y.; Qi, X.; Sun, J.; Miao, L.; Yang, C. Retromer is required for apoptotic cell clearance by phagocytic receptor recycling. Science 2010, 327, 1261-1264. [CrossRef] 
57. Lieu, Z.Z.; Gleeson, P.A. Identification of different itineraries and retromer components for endosome-to-Golgi transport of TGN38 and Shiga toxin. Eur. J. Cell Biol. 2010, 89, 379-393. [CrossRef]

58. Robinson, D.G.; Neuhaus, J.M. Receptor-mediated sorting of soluble vacuolar proteins: Myths, facts, and a new model. J. Exp. Bot. 2016, 67, 4435-4449. [CrossRef]

59. Okada, H.; Zhang, W.; Peterhoff, C.; Hwang, J.C.; Nixon, R.A.; Ryu, S.H.; Kim, T.W. Proteomic identification of sorting nexin 6 as a negative regulator of BACE1-mediated APP processing. FASEB J. 2010, 24, 2783-2794. [CrossRef]

60. Jaillais, Y.; Santambrogio, M.; Rozier, F.; Fobis-Loisy, I.; Miege, C.; Gaude, T. The retromer protein VPS29 links cell polarity and organ initiation in plants. Cell 2007, 130, 1057-1070. [CrossRef]

61. Traer, C.J.; Rutherford, A.C.; Palmer, K.J.; Wassmer, T.; Oakley, J.; Attar, N.; Carlton, J.G.; Kremerskothen, J.; Stephens, D.J.; Cullen, P.J. SNX4 coordinates endosomal sorting of TfnR with dynein-mediated transport into the endocytic recycling compartment. Nat. Cell Biol. 2007, 9, 1370-1380. [CrossRef]

62. Kim, N.Y.; Cho, M.H.; Won, S.H.; Kang, H.J.; Yoon, S.Y.; Kim, D.H. Sorting nexin-4 regulates $\beta$-amyloid production by modulating $\beta$-site-activating cleavage enzyme-1. Alzheimers Res. Ther. 2017, 9, 4. [CrossRef] [PubMed]

63. Solis, G.P.; Hulsbusch, N.; Radon, Y.; Katanaev, V.L.; Plattner, H.; Stuermer, C.A. Reggies/flotillins interact with Rab11a and SNX4 at the tubulovesicular recycling compartment and function in transferrin receptor and E-cadherin trafficking. Mol. Biol. Cell 2013, 24, 2689-2702. [CrossRef] [PubMed]

64. Knaevelsrud, H.; Carlsson, S.R.; Simonsen, A. SNX18 tubulates recycling endosomes for autophagosome biogenesis. Autophagy 2013, 9, 1639-1641. [CrossRef] [PubMed]

65. van Weering, J.R.; Verkade, P.; Cullen, P.J. SNX-BAR proteins in phosphoinositide-mediated, tubular-based endosomal sorting. Semin. Cell Dev. Biol. 2010, 21, 371-380. [CrossRef]

66. Li, H.; Li, H.F.; Felder, R.A.; Periasamy, A.; Jose, P.A. Rab4 and Rab11 coordinately regulate the recycling of angiotensin II type I receptor as demonstrated by fluorescence resonance energy transfer microscopy. J. Biomed. Opt. 2008, 13, 031206. [CrossRef]

67. Li, H.; Yu, P.; Sun, Y.; Felder, R.A.; Periasamy, A.; Jose, P.A. Actin cytoskeleton-dependent Rab GTPase-regulated angiotensin type I receptor lysosomal degradation studied by fluorescence lifetime imaging microscopy. J. Biomed. Opt. 2010, 15, 056003. [CrossRef]

68. Li, H.; Armando, I.; Yu, P.; Escano, C.; Mueller, S.C.; Asico, L.; Pascua, A.; Lu, Q.; Wang, X.; Villar, V.A.; et al. Dopamine 5 receptor mediates Ang II type 1 receptor degradation via a ubiquitin-proteasome pathway in mice and human cells. J. Clin. Invest. 2008, 118, 2180-2189. [CrossRef]

69. McNally, K.E.; Cullen, P.J. Endosomal retrieval of cargo: Retromer is not alone. Trends Cell Biol. 2018, 28, 807-822. [CrossRef] [PubMed]

70. Simonetti, B.; Danson, C.M.; Heesom, K.J.; Cullen, P.J. Sequence-dependent cargo recognition by SNX-BARs mediates retromerindependent transport of CI-MPR. J. Cell Biol. 2017, 216, 3695-3712. [CrossRef]

71. Yong, X.; Zhao, L.; Deng, W.; Sun, H.; Zhou, X.; Mao, L.; Hu, W.; Shen, X.; Sun, Q.; Billadeau, D.D.; et al. Mechanism of cargo recognition by retromer-linked SNX-BAR proteins. PLoS. Biol. 2020, 18, e3000631. [CrossRef] [PubMed]

72. Masuho, I.; Balaji, S.; Muntean, B.S.; Skamangas, N.K.; Chavali, S.; Tesmer, J.J.G.; Babu, M.M.; Martemyanov, K.A. A global map of $G$ protein signaling regulation by RGS proteins. Cell 2020, 183, 503-521. [CrossRef]

73. Ma, M.; Burd, C.G. Retrograde trafficking and plasma membrane recycling pathways of the budding yeast Saccharomyces cerevisiae. Traffic 2020, 21, 45-59. [CrossRef]

74. van Weering, J.R.; Sessions, R.B.; Traer, C.J.; Kloer, D.P.; Bhatia, V.K.; Stamou, D.; Carlsson, S.R.; Hurley, J.H.; Cullen, P.J. Molecular basis for SNX-BAR-mediated assembly of distinct endosomal sorting tubules. EMBO J. 2012, 31, 4466-4480. [CrossRef]

75. Seaman, M.N.J. Retromer and the cation-independent mannose 6-phosphate receptor-time for a trial separation? Traffic 2018, 19, 150-152. [CrossRef] [PubMed]

76. Norris, A.; Tammineni, P.; Wang, S.; Gerdes, J.; Murr, A.; Kwan, K.Y.; Cai, Q.; Grant, B.D. SNX-1 and RME-8 oppose the assembly of HGRS-1/ESCRT-0 degradative microdomains on endosomes. Proc. Natl. Acad. Sci. USA 2017, 114, E307-E316. [CrossRef]

77. Norris, A.; Grant, B.D. Endosomal microdomains: Formation and function. Curr. Opin. Cell Biol. 2020, 65, 86-95. [CrossRef]

78. Simonetti, B.; Paul, B.; Chaudhari, K.; Weeratunga, S.; Steinberg, F.; Gorla, M.; Heesom, K.J.; Bashaw, G.J.; Collins, B.M.; Cullen, P.J. Molecular identification of a BAR domain-containing coat complex for endosomal recycling of transmembrane proteins. Nat. Cell Biol. 2019, 21, 1219-1233. [CrossRef] [PubMed]

79. Dores, M.R.; Trejo, J. Endo-lysosomal sorting of G-protein-coupled receptors by ubiquitin: Diverse pathways for G-proteincoupled receptor destruction and beyond. Traffic 2019, 20, 101-109. [CrossRef]

80. Schwihla, M.; Korbei, B. The Beginning of the end: Initial steps in the degradation of plasma membrane proteins. Front Plant Sci. 2020, 11, 680. [CrossRef] [PubMed]

81. Greaves, J.; Prescott, G.R.; Gorleku, O.A.; Chamberlain, L.H. The fat controller: Roles of palmitoylation in intracellular protein trafficking and targeting to membrane microdomains (Review). Mol. Membr. Biol. 2009, 26, 67-79. [CrossRef] [PubMed]

82. Tortosa, E.; Hoogenraad, C.C. Polarized trafficking: The palmitoylation cycle distributes cytoplasmic proteins to distinct neuronal compartments. Curr. Opin. Cell Biol. 2018, 50, 64-71. [CrossRef] [PubMed]

83. Jean-Charles, P.Y.; Snyder, J.C.; Shenoy, S.K. Chapter One-Ubiquitination and deubiquitination of G protein-coupled receptors. Prog. Mol. Biol. Transl. Sci. 2016, 141, 1-55. 
84. Williams, R.L.; Urbe, S. The emerging shape of the ESCRT machinery. Nat. Rev. Mol. Cell Biol. 2007, 8, 355-368. [CrossRef] [PubMed]

85. Lucas, M.; Gershlick, D.C.; Vidaurrazaga, A.; Rojas, A.L.; Bonifacino, J.S.; Hierro, A. Structural mechanism for cargo recognition by the retromer complex. Cell 2016, 167, 1623-1635.e1614. [CrossRef]

86. Bottcher, R.T.; Stremmel, C.; Meves, A.; Meyer, H.; Widmaier, M.; Tseng, H.Y.; Fassler, R. Sorting nexin 17 prevents lysosomal degradation of beta1 integrins by binding to the $\beta 1$ - integrin tail. Nat. Cell Biol. 2012, 14, 584-592. [CrossRef]

87. McNally, K.E.; Faulkner, R.; Steinberg, F.; Gallon, M.; Ghai, R.; Pim, D.; Langton, P.; Pearson, N.; Danson, C.M.; Nagele, H.; et al. Retriever is a multiprotein complex for retromer-independent endosomal cargo recycling. Nat. Cell Biol. 2017, 19, 1214-1225. [CrossRef]

88. Clairfeuille, T.; Mas, C.; Chan, A.S.M.; Yang, Z.; Tello-Lafoz, M.; Chandra, M.; Widagdo, J.; Kerr, M.C.; Paul, B.; Mérida, I.; et al. A molecular code for endosomal recycling of phosphorylated cargos by the SNX27-retromer complex. Nat. Struct. Mol. Biol. 2016, 23, 921. [CrossRef] [PubMed]

89. Zechi-Ceide, R.M.; Rodrigues, M.G.; Jehee, F.S.; Kokitsu-Nakata, N.M.; Passos-Bueno, M.R.; Guion-Almeida, M.L. SaethreChotzen phenotype with learning disability and hyper IgE phenotype in a patient due to complex chromosomal rearrangement involving chromosomes 3 and 7. Am. J. Med. Genet. A 2012, 158, 1680-1685. [CrossRef]

90. Huang, H.S.; Yoon, B.J.; Brooks, S.; Bakal, R.; Berrios, J.; Larsen, R.S.; Wallace, M.L.; Han, J.E.; Chung, E.H.; Zylka, M.J.; et al. Snx14 regulates neuronal excitability, promotes synaptic transmission, and is imprinted in the brain of mice. PLoS ONE 2014, 9, e98383. [CrossRef]

91. Bryant, D.; Seda, M.; Peskett, E.; Maurer, C.; Pomeranz, G.; Ghosh, M.; Hawkins, T.A.; Cleak, J.; Datta, S.; Hariri, H.; et al. Diverse species-specific phenotypic consequences of loss of function sorting nexin 14 mutations. Sci. Rep. 2020, 10, 13763. [CrossRef]

92. Hu, Y.F.; Zhang, H.L.; Cai, T.; Harashima, S.; Notkins, A.L. The IA-2 interactome. Diabetologia 2005, 48, 2576-2581. [CrossRef] [PubMed]

93. Bard, M.P.; Hegmans, J.P.; Hemmes, A.; Luider, T.M.; Willemsen, R.; Severijnen, L.A.; van Meerbeeck, J.P.; Burgers, S.A.; Hoogsteden, H.C.; Lambrecht, B.N. Proteomic analysis of exosomes isolated from human malignant pleural effusions. Am J Respir Cell Mol Biol. 2004, 31, 114-121. [CrossRef] [PubMed]

94. Muglia, M.; Magariello, A.; Citrigno, L.; Passamonti, L.; Sprovieri, T.; Conforti, F.L.; Mazzei, R.; Patitucci, A.; Gabriele, A.L.; Ungaro, C.; et al. A novel locus for dHMN with pyramidal features maps to chromosome 4q34.3-q35.2. Clin. Genet. 2008, 73, 486-491. [CrossRef] [PubMed]

95. Pedersen, H.K.; Gudmundsdottir, V.; Brunak, S. Pancreatic islet protein complexes and their dysregulation in type 2 diabetes. Front Genet. 2017, 8, 43. [CrossRef]

96. Mulindwa, J.; Noyes, H.; Ilboudo, H.; Pagani, L.; Nyangiri, O.; Kimuda, M.P.; Ahouty, B.; Asina, O.F.; Ofon, E.; Kamoto, K.; et al. High levels of genetic diversity within Nilo-Saharan populations: Implications for human adaptation. Am. J. Hum. Genet. 2020, 107, 473-486. [CrossRef]

97. Ebrahimi-Fakhari, D. Congenital disorders of autophagy: What a pediatric neurologist should know. Neuropediatrics 2018, 49, 18-25. [CrossRef]

98. Ma, L.; Semick, S.A.; Chen, Q.; Li, C.; Tao, R.; Price, A.J.; Shin, J.H.; Jia, Y. BrainSeq Consortium, Brandon, N.J.; Cross, A.J.; et al. Schizophrenia risk variants influence multiple classes of transcripts of sorting nexin 19 (SNX19). Mol. Psychiatry 2020, 25, 831-843. [CrossRef]

99. Martin, A.R.; Lin, M.; Granka, J.M.; Myrick, J.W.; Liu, X.; Sockell, A.; Atkinson, E.G.; Werely, C.J.; Möller, M.; Sandhu, M.S.; et al. An unexpectedly complex architecture for skin pigmentation in Africans. Cell 2017, 171, 1340-1353.e14. [CrossRef]

100. Ugrankar, R.; Bowerman, J.; Hariri, H.; Chandra, M.; Chen, K.; Bossanyi, M.F.; Datta, S.; Rogers, S.; Eckert, K.M.; Vale, G.; et al. Drosophila snazarus regulates a lipid droplet population at plasma membrane-droplet contacts in adipocytes. Dev. Cell 2019, 50, 557-572.e5. [CrossRef] [PubMed]

101. Hugenroth, M.; Bohnert, M. Come a little bit closer! Lipid droplet-ER contact sites are getting crowded. Biochim. Biophys. Acta Mol. Cell Res. 2020, 1867, 118603. [CrossRef] [PubMed]

102. Hines, R.M.; Kang, R.; Goytain, A.; Quamme, G.A. Golgi-specific DHHC zinc finger protein GODZ mediates membrane Ca ${ }^{2+}$ transport. J. Biol. Chem. 2010, 285, 4621-4628. [CrossRef] [PubMed]

103. Felder, R.A.; Sanada, H.; Xu, J.; Yu, P.Y.; Wang, Z.; Watanabe, H.; Asico, L.D.; Wang, W.; Zheng, S.; Yamaguchi, I.; et al. G protein-coupled receptor kinase 4 gene variants in human essential hypertension. Proc. Natl. Acad. Sci. USA 2002, 99, 3872-3877. [CrossRef] [PubMed]

104. Li, H.; Han, W.; Villar, V.A.; Keever, L.B.; Lu, Q.; Hopfer, U.; Quinn, M.T.; Felder, R.A.; Jose, P.A.; Yu, P. D1-like receptors regulate NADPH oxidase activity and subunit expression in lipid raft microdomains of renal proximal tubule cells. Hypertension 2009, 53, 1054-1061. [CrossRef] [PubMed]

105. Han, W.; Li, H.; Villar, V.A.; Pascua, A.M.; Dajani, M.I.; Wang, X.; Natarajan, A.; Quinn, M.T.; Felder, R.A.; Jose, P.A.; et al. Lipid rafts keep NADPH oxidase in the inactive state in human renal proximal tubule cells. Hypertension 2008, 51, 481-487. [CrossRef] [PubMed]

106. Xu, J.; Li, X.X.; Albrecht, F.E.; Hopfer, U.; Carey, R.M.; Jose, P.A. Dopamine(1) receptor, Gs $\alpha$, and Na(+)-H(+) exchanger interactions in the kidney in hypertension. Hypertension 2000, 36, 395-399. [CrossRef] 